\title{
Branchial lesions associated with abundant apoptotic cells in oysters Ostrea edulis of Galicia (NW Spain)
}

\author{
P. Mirella da Silva ${ }^{1}$, Antonio Villalba ${ }^{1, *}$, Inke Sunila ${ }^{2}$ \\ ${ }^{1}$ Centro de Investigacións Mariñas, Consellería de Pesca e Asuntos Marítimos, Xunta de Galicia, Aptdo. 13, \\ 36620 Vilanova de Arousa, Spain \\ ${ }^{2}$ State of Connecticut Department of Agriculture, Bureau of Aquaculture, Milford, Connecticut 06460, USA
}

\begin{abstract}
An experiment to evaluate differences in growth, mortality and disease susceptibility among Ostrea edulis stocks was performed. Five families were produced from each of 4 oyster populations (Irish, Greek and 2 Galician). The spat were transferred to a raft in the Ría de Arousa (Galicia, Spain) for grow-out. Monthly samples of each family were histologically processed from 2001 to 2003. One of the pathological conditions discovered by this study was the occurrence of extensive branchial lesions characterized by haemocytic infiltration and loss of branchial architecture. Furthermore, abundant atypical cells occurred among the haemocytes in the lesions in the branchial connective and epithelial tissues, but rarely in the mantle. These cells were contracted in size with nuclei showing chromatin condensation and fragmentation. Some nuclear chromatin aggregated under the nuclear membranes into crescent shapes, whereas others were uniformly dense. Those characteristics suggested that the cells were apoptotic haemocytes, which was confirmed by transmission electron microscopy (TEM) and by a terminal deoxynucleotidyl transferase (TdT)-mediated dUTP nick end labelling (TUNEL) assay using the Apoptag ${ }^{\circledR}$ Kit on paraffin sections. A low prevalence of gill lesions was detected in some, but not all, families of every origin peaking in July 2002 and April 2003. No etiologic agent was identified by either histology or TEM; thus, the cause of the abundance of apoptotic cells remains unclear.
\end{abstract}

KEY WORDS: Branchial lesions $\cdot$ Apoptosis $\cdot$ TEM $\cdot$ Ostrea edulis $\cdot$ Bivalve

\section{INTRODUCTION}

Apoptosis is a tightly regulated process of programmed cell death in which cells play an active role in their own death. Apoptosis is a normal component of the development and health of multicellular organisms (see review of White 1996). In contrast, necrosis is an accidental, uncontrolled cell death, which leads to the lysis of cells and triggers an inflammatory response. Necrosis occurs when cells are exposed to serious physical or chemical stress. Thus, apoptosis and necrosis represent 2 extremes on the continuum of cell death. There are distinct biochemical and morphological characteristics during apoptosis and necrosis. When a cell is undergoing apoptosis, the cytoplasm shrinks, the nucleus condenses and the cell membrane shows blebs or spikes (protrusions of the cell membrane) that can become detached from the dying cell to form apoptotic bodies composed of membrane-bound cytoplasm, nuclear fragments and organelles. The apoptotic bodies are later engulfed by phagocytic cells without eliciting an inflammatory response (Vermes \& Haanen 1994) since the cell membrane preserves its integrity. In apoptosis, a specific endonuclease breaks the DNA into fragments of 180-200 base pairs or multiples thereof (Wyllie 1980). During necrosis, the cytoplasm and mitochondria swell, the nuclei conserve their pattern and there is no apoptotic body formation. On histological sections, apoptosis can be detected by analysing the characteristic DNA fragmentation using the terminal deoxynucleotidyl transferase (TdT)-mediated dUTP nick end 
labelling (TUNEL) assay. This method is based on the specific binding of digoxigenin-labelled nucleotides to $3^{\prime} \mathrm{OH}$ ends of DNA fragments by the enzyme TdT. An anti-digoxigen antibody conjugated to peroxidase binds to the digoxygenin-labelled nucleotides and is observed after treatment with a chromogenic peroxidase substrate, thus creating a distinguishable stain for immunohistochemical detection (Gavrieli et al. 1992).

Only a few studies report apoptosis in bivalves, especially those related to the morphological changes in the cells. Only one publication briefly described ultrastructural features of apoptotic cells (Renault et al. 2000). Those authors aimed to report the infection of 2 oyster species (Crassostrea gigas and Ostrea edulis) by a herpes-like virus. Most articles about bivalve apoptosis deal with the function/effect of certain compounds on apoptosis activation and the highlighted similarity to the apoptotic processes in human cells. Terahara et al. (2003) induced apoptosis in C. gigas haemocytes with Arg-Gly-Asp (RGD) peptides. The RGD peptides have been used in many human cell types as inhibitors of integrin-ligand interactions and are well known to induce apoptosis integrin-dependently or -independently, for example, by direct caspase activation (Aoshiba et al. 1997, Buckley et al. 1999). Cadmium induced apoptosis in oyster C. virginica haemocytes in a dose-dependent manner (Sokolova et al. 2004) similar to vertebrate cells (de la Fuente et al. 2002), and tri$n$-butyltin also induced apoptotic processes in gills of the mussel Mytilus galloprovincialis (Mičić et al. 2001, 2002). Lacoste et al. (2002) studied the induction and signaling pathway of apoptosis in oyster $C$. gigas haemocytes and suggested that noradrenaline can elicit apoptosis via the b-adrenoceptor-mediated activator of adenylate cyclase and c-adenosine monophosphate (AMP)-dependent protein kinase. In addition, some publications focused on apoptosis of oyster $C$. virginica haemocytes and Perkinsus marinus cells. Sunila \& LaBanca (2003) demonstrated that C. virginica haemocytes infected by $P$. marinus had less apoptosis than haemocytes from non-infected oysters. The authors suggested that this intracellular parasite had manipulated haemocyte apoptosis to provide more host cells for itself for enhanced proliferation and survival. Recently, Goedken et al. (2005a) showed that lower salinity induced more apoptosis of $P$. marinus in vitro than higher salinity. In another paper, Goedken et al. (2005b) compared differences in haemocyte apoptosis between experimentally infected $C$. virginica and $C$. gigas and noted that while $P$. marinus infection suppressed haemocyte apoptosis in both species, C. gigas appeared to overcome that supression faster than $C$. virginica. They speculated that this might explain the better resistance of $C$. gigas to $P$. marinus disease.
In the present study we report for the first time the occurrence of apoptosis associated with extensive branchial lesions in the flat oyster Ostrea edulis. We also describe the morphological characteristics of these cells and the prevalence of gill lesions associated with apoptosis profusion during 2 yr of grow-out in the Ría de Arousa (NW Spain).

\section{MATERIALS AND METHODS}

Production of oyster families. Four oyster populations were selected as broodstocks for the experiments: 1 in the north of Ireland (IR), 1 in Greece (GR) and 2 in Galicia (NW Spain), i.e. 1 in Ría de Ortigueira (OR) and 1 in Coroso (CO) (Ría de Arousa). The oysters from each origin were transported to the hatchery facilities of Centro de Investigacións Mariñas (CIMA) in December 2000 and distributed into 5 trays per broodstock with 15 to 20 ind. per tray, resulting in 20 trays. Oysters were conditioned for 2 to 3 mo in running seawater as described by da Silva et al. (2005). The larvae from each batch originated from a single mother, thus being either one-half or full sibling families, and were reared according to the procedure described by Román (1992). Once spat surpassed $1 \mathrm{~cm}$ in height, they were transferred to a raft for grow-out. A total of 19 families were produced; 5 from each origin, except for IR, from which only 4 families were obtained.

Experimental design for oyster raft grow-out. The experiment for oyster grow-out was designed to determine various parameters (growth, mortality and disease susceptibility) in a research programme (da Silva et al. 2005). In September 2001, approximately 4000 ind. from each family were transferred to a raft located near Cambados (Ría de Arousa, Galicia, NW Spain). The oyster spat was distributed into lidded containers (250 ind. per container) made of $1 \mathrm{~cm}$ mesh plastic net. Each container was marked to identify the spat family inside. The containers were set in standard perforated $(2 \mathrm{~cm}$ mesh) circular plastic trays for oyster culture ( 4 containers per tray). The trays were piled in stacks of 10 trays (8 stacks in total) and hung from a raft. Each stack of trays hosted 2 containers of each spat family, which were randomly placed in the stack, in a randomised complete block design. Thus, each family was represented, twice, in every stack of trays (block). Two stacks of trays were randomly selected every month for sampling in order to estimate the growth and the mortality and to diagnose pathological conditions. The number of individuals per container was reduced as oysters grew; thus, the number of trays increased. The use of spat containers ceased in June 2002, and oysters were directly set in the trays to 
favour water renewal through oysters. After June 2002, because no significant difference either in growth or mortality was found between stacks of trays (blocks), oysters were rearranged to set oysters of the same family in the same stack of trays. Consequently, the sampling design was also modified into a hierarchical design, with families nested under origins. Two replicates were taken for monthly mortality percentages by counting dead and live oysters. Each month 10 oysters per family were randomly taken for disease diagnosis until June 2002. Beginning in July 2000, 6 oysters were taken monthly for each family. After $2 \mathrm{yr}$ of raft culture, sampling finished in September 2003. The families IR1, IR2 and IR4 reached $100 \%$ cumulative mortality before the end of the experiment.

Analysis of pathological conditions. The occurrence of pathological conditions was primarily evaluated by examining histological sections. Oysters were shucked and a sagital, approximately $5 \mathrm{~mm}$ thick section of meat containing gill, visceral mass and mantle lobes was excised, fixed in Davidson's solution and embedded in paraffin. Tissue sections $(5 \mu \mathrm{m})$ were stained with Harris' hematoxylin and eosin. In addition, small fragments of gill and visceral mass of some of the oysters sampled for histology were fixed in $2.5 \%$ glutaraldehyde (in 0.2 M cacodylate buffer, $\mathrm{pH}$ 7.2) for $2 \mathrm{~h}$ at $4^{\circ} \mathrm{C}$, washed and stored in the same buffer at $4^{\circ} \mathrm{C}$ for eventual transmission electron microscopy (TEM) examination. Once the histological sections had been examined, the stored tissues of those oysters found to be affected were further processed for TEM: the gill and visceral mass fragments were postfixed in buffered $1 \% \mathrm{OsO}_{4}$ for $2 \mathrm{~h}$ at $4{ }^{\circ} \mathrm{C}_{\text {; }}$ after dehydration in an ethanol series, the material was embedded in Epon, sectioned, double stained with uranyl acetate and lead citrate, and observed in a JEOL 1010 transmission microscope operated at $80 \mathrm{kV}$. The monthly prevalence of branchial lesions was calculated as the percentage of affected oysters in each sample.

In situ apoptosis detection by TUNEL assay. Paraffin blocks of 15 oysters in which branchial lesions of different intensity (differences in abundance of atypical cells) had been detected by histological examination, and 12 oysters with no sign of branchial lesions were selected to perform TUNEL assay. Those oysters had been taken in July and August 2002 and corresponded to 12 oyster families derived from 4 different broodstocks. In situ apoptosis detection was performed by TUNEL assay using Apoptag $^{\circledR}$, a peroxidase-based apoptosis detection kit (Intergen). Tissue sections (5 mm) were placed on positively charged slides. Deparaffinized sections were rehydrated with ethanol before being put in phosphate buffered saline (PBS). The tissues were then pretreated with Proteinase K (20 $\mathrm{mg} \mathrm{ml}^{-1}, 15 \mathrm{~min}$, room temperature) and $0.5 \%(\mathrm{w}: \mathrm{v})$
Triton X-100 in PBS (10 min). They were quenched in $3 \%$ hydrogen peroxide in PBS for $5 \mathrm{~min}$, rinsed in water, and treated with ApopTag ${ }^{\circledR}$ equilibration buffer. The tissues were then incubated with TdT and nucleotides $\left(1 \mathrm{~h}, 37^{\circ} \mathrm{C}\right)$. After incubation, the tissues were treated with ApopTag ${ }^{\circledR}$ stop/wash buffer, followed by an anti-digoxigenin peroxidase conjugate (30 min, room temperature). After a wash in PBS, tissues were stained with a peroxidase substrate. Tissues were counter-stained in a $0.5 \%(\mathrm{w}: \mathrm{v})$ methyl green solution. The sections were dehydrated and mounted. Two positive controls were used; one was normal postweaning female rat mammary gland, included in the Apoptag $^{\circledR}$ kit, while the other consisted of slides of Crassostrea virginica infected with Perkinsus marinus in which some parasite cells were apoptotic. Two negative controls were used; for one control water was substituted for TdT, while in the other rehydrated slides were stained with peroxidase substrate without adding TdT or antibody conjugate to detect possible endogenous peroxidase activity.

\section{RESULTS}

The examination of histological sections revealed the occurrence of symbionts and pathological conditions in oysters during 2 yr of culture in the Ría de Arousa (da Silva et al. 2005). One of the pathological conditions detected was the presence of extensive branchial lesions. The affected oysters did not exhibit external signs of gill injury under macroscopic examination, except 1 with some indentations. In histological sections, the gill lesions consisted of wide areas infiltrated by normal haemocytes and abundant atypical cells (Fig. 1), possibly apoptotic haemocytes. On a few occasions lesions were also detected in the mantle. The amount of infiltrated areas and the parts of the gill involved varied according to the individual. Some of them presented few, $50 \mathrm{~mm}$ (larger dimension), foci of infiltrated atypical cells in the connective tissue of the plicae and interlamellar junctions. Others exhibited multifocal infiltrations involving several filaments and plicae along the lamella. In such cases, the lesions could reach $1000 \mathrm{~mm}$ in size (larger dimension) and loss of the normal architecture of gills was evident (Fig. 1). Also, oysters frequently had abundant atypical cells which did not form a focus, but rather spread to the connective tissue along the entire demibranch. The gill epithelium was observed sloughing on a few occasions.

The atypical cells observed in the connective tissue of the gill had small round or crescent nuclei, were extremely basophilic and the cytoplasm was also reduced in size and strongly acidophilic (Figs. 2 to 4 ). 

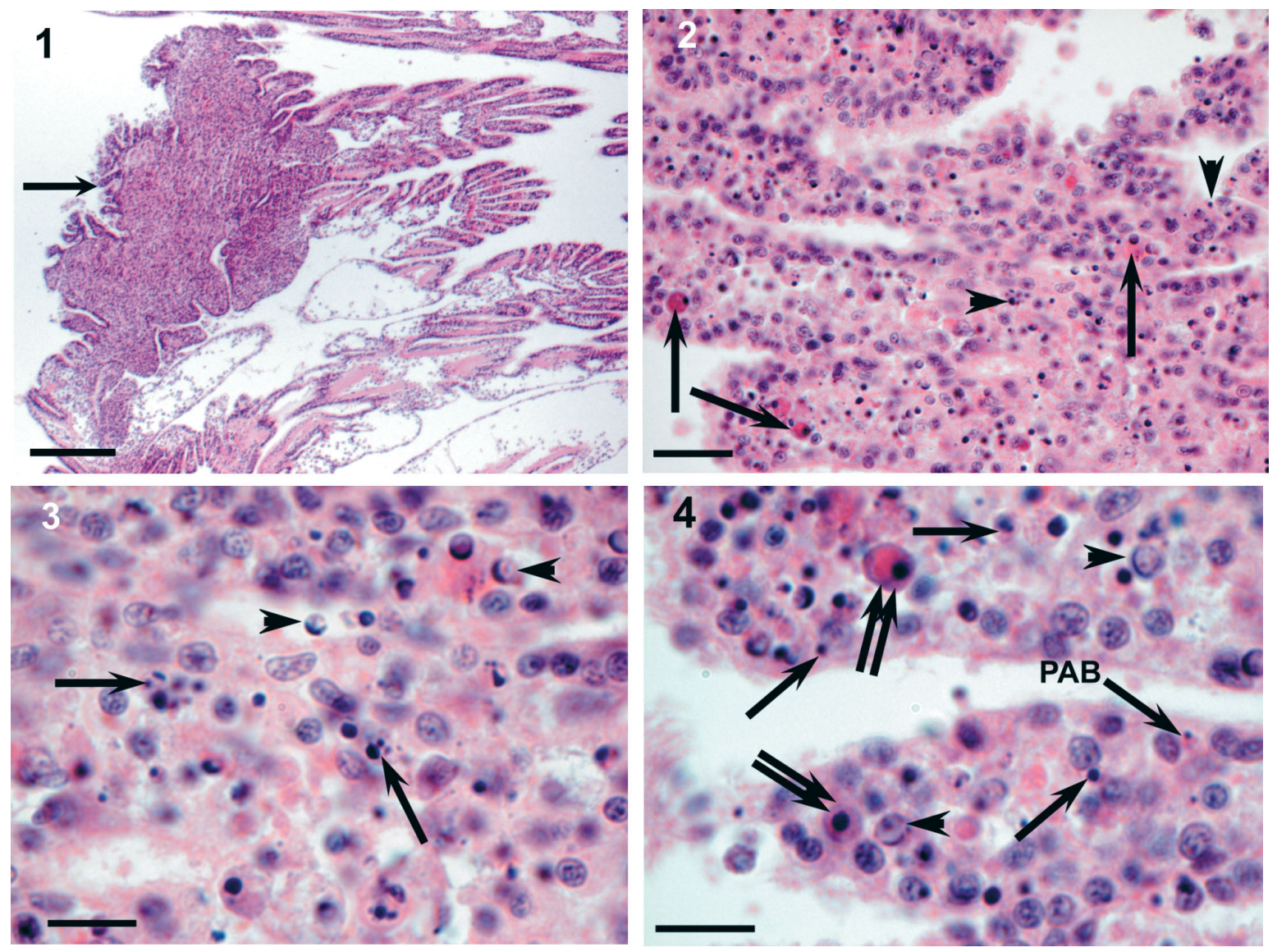

Figs. 1 to 4. Ostrea edulis. Branchial lesions associated with abundant apoptotic cells in oysters. Images of histological sections. Fig. 1. Cross section of a gill lamella showing an area (arrow) whose normal architecture has been lost. Scale bar $=200 \mu \mathrm{m}$. Fig. 2. Branchial lesion showing apoptotic cells of different sizes, with acidophilic cytoplasm (arrows) and condensed and fragmented basophilic nuclei (arrowheads). Scale bar $=20 \mu \mathrm{m}$. Fig. 3. Magnification of a gill lesion showing some cells with crescent nuclei (arrowheads). Arrows point at apoptotic bodies. Scale bar $=10 \mu \mathrm{m}$. Fig. 4. Magnification of a gill lesion showing cells with some crescent nuclei (arrowheads), condensed nucleus (arrows), phagocytosed apoptotic bodies (PAB) and cells with acidophilic cytoplasm (double arrows). Scale bar $=10 \mu \mathrm{m}$

The major ultrastructural change was detected in the nucleus of the apoptotic cells, which revealed a patent reduction in size (Fig. 5). In some cells, the nucleus broke into fragments giving rise to apoptotic bodies (Fig. 6). Condensed nuclear chromatin became marginal, producing crescent or almost ring shapes (Figs. 7 \& 8) and sometimes formed aggregations under the nuclear membrane (Fig. 9). The contraction of nuclei caused detachment of the nuclear membranes that projected into the cytoplasmic matrix and formed wide perinuclear spaces (Figs. 6 to 10). Few cytoplasmic organelles such as mitochondria and Golgi complex (Figs. 5, 8 \& 10) were observed, and some signs of cytoplasmic degeneration were observed. The cell membrane was often intact and apoptotic cells were observed being ingested by phagocytic cells (Fig. 5). Few cells showed abundant free ribosomes (Fig. 9). No etiologic agent was identified by either histology or TEM.
The TUNEL assay confirmed the occurrence of apoptosis in the oyster tissues. A total of 14 out of 15 oysters analysed showed brown deposits in cells occurring in the connective tissue of the gills with lesions. The abundance of apoptotic cells differed from oyster to oyster depending on the severity of the lesion. Most oysters (9) showed high numbers of apoptotic cells (Figs. 11 to 13) associated with haemocytic infiltration while fewer cases (5) showed low proportion of apoptosis in gill lesions. A few cells undergoing apoptosis were also observed in the epithelia of the mantle, intestine (Fig. 15), digestive diverticula and in the gonad follicles (Fig. 16) of oysters with branchial lesions. In addition, one case of abundant apoptosis occurred in the epithelia of labial palps. Oysters without lesions did not show brown deposits in the gills (Fig. 14). However, 1 out of the 12 oysters used as controls without initially apparent gill lesions had apoptotic cells in the gills. Later examination of a 

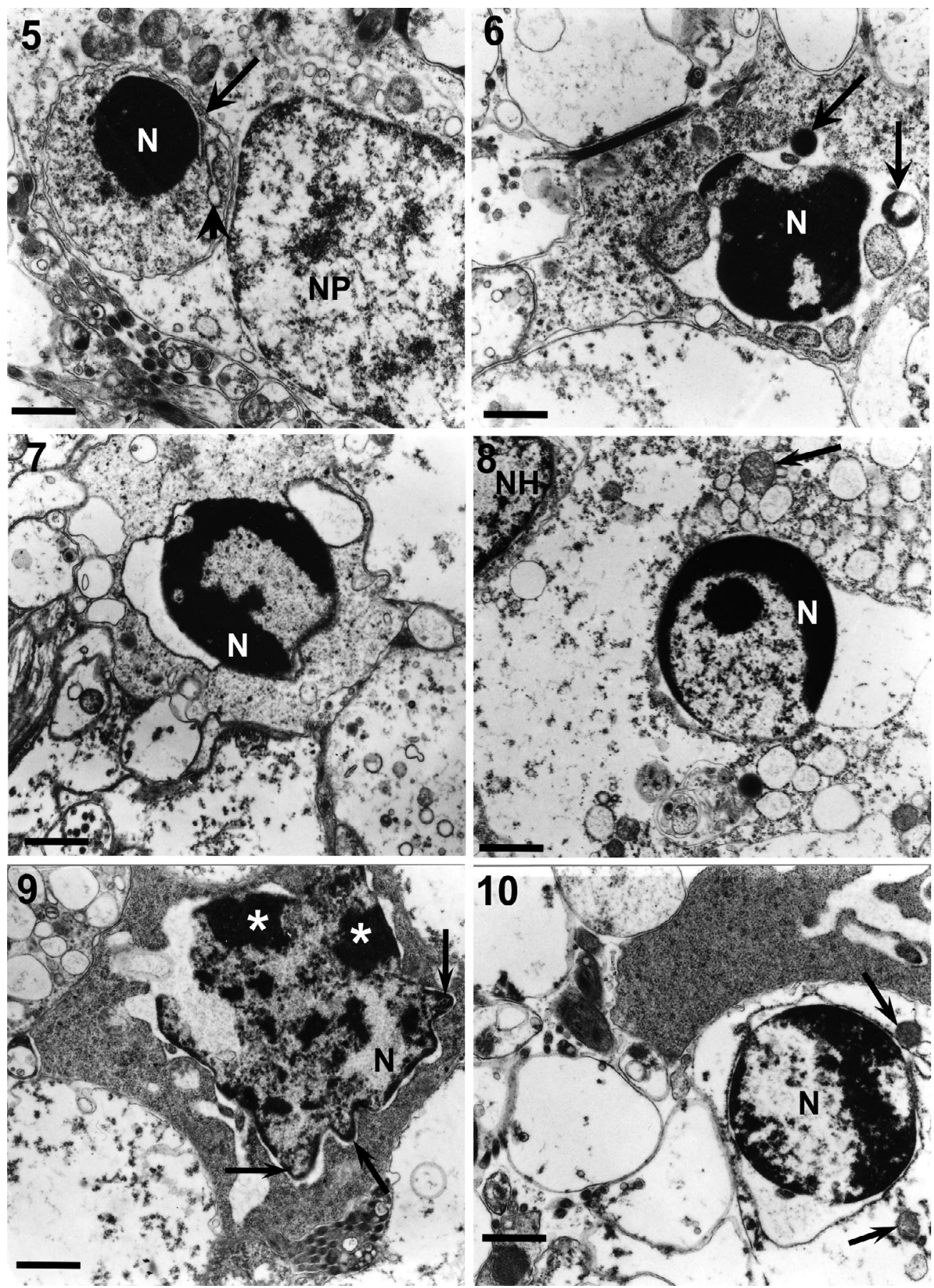

Figs. 5 to 10. Ostrea edulis. Apoptotic cells in branchial lesions of oysters.Transmission electron micrographs. Fig. 5. Phagocytosed apoptotic body showing a condensed nucleus $(\mathrm{N})$, vesicles of the Golgi complex (arrowhead) and endoplasmic reticulum (arrow) in its cytoplasm. The plasma membrane is intact. NP: nucleus of the phagocytic cell. Scale bar $=600 \mathrm{~nm}$. Fig. 6 . Apoptotic cell with a highly condensed nuclei $(\mathrm{N})$, showing blebs and spikes giving rise to apoptotic bodies (arrows). Scale bar $=600 \mathrm{~nm}$. Fig. 7. Apoptotic cell whose nucleus $(\mathrm{N})$ shows chromatin condensation with a ring-like shape. The outer nuclear membrane is detached from the inner nuclear membrane, forming wide spaces. Scale bar $=800 \mathrm{~nm}$. Fig. 8. Apoptotic cell whose nucleus (N) shows chromatin condensation with a crescent shape. Some vacuoles and a mitochondrion (arrow) present in their cytoplasm. $\mathrm{NH}$ : nucleus of a healthy cell. Scale bar $=1 \mu \mathrm{m}$. Fig. 9. Apoptotic cell whose nucleus (N) shows protrusions (arrows) and chromatin condensation forming masses $(*)$ distributed throughout its periphery. Cytoplasm shows numerous ribosomes. Scale bar $=800 \mathrm{~nm}$. Fig. 10. Apoptotic cell whose nucleus (N) shows chromatin condensation and expansions of the outer nuclear membrane. Cytoplasm appears deteriorated and shows some mitochondria (arrows). Scale bar $=600 \mathrm{~nm}$ 
deeper section of the histological block ascertained that this oyster had a previously undetected gill lesion.

A very low prevalence of this pathological condition was detected in oysters of all origins and 14 families. Most cases occurred from May to August 2002, with a peak in July 2002 (50\%), and reappeared in April 2003 (Figs. $17 \& 18$ ). The stock of Irish origin had the highest mean prevalence $(1.6 \%)$ and the stock of Coroso origin had the lowest $(0.6 \%)$.

\section{DISCUSSION}

The histological examination of sections did not reveal any pathogen that could have caused the branchial lesions associated with the profusion of apoptotic cells in the oysters. Some pathogens have developed the ability to induce apoptosis in human cells, indicating multiple mechanisms of hostpathogen interaction (Barcinski \& DosReis 1999,
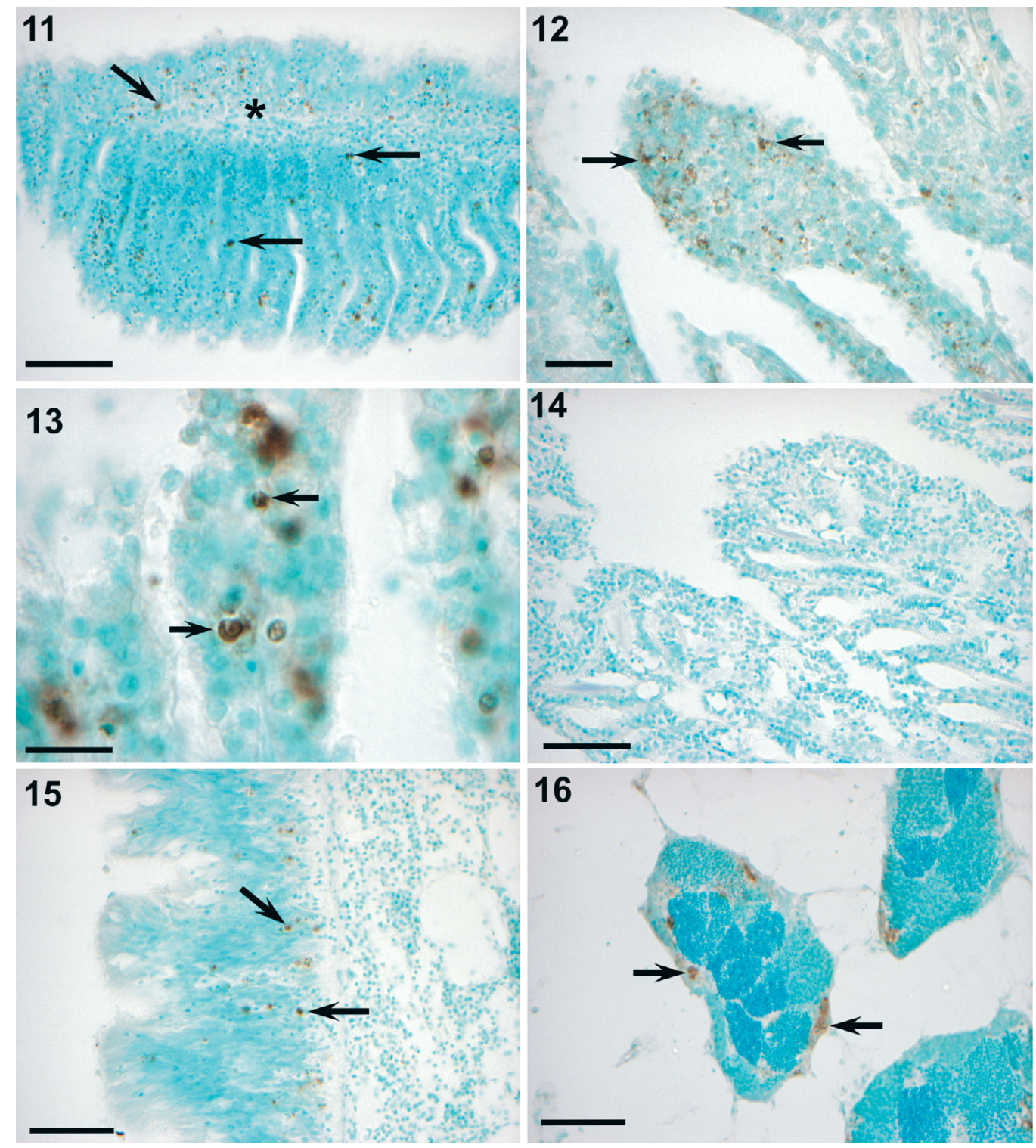

Figs. 11 to 16. Ostrea edulis. Figs. 11 to 14. Branchial lesions associated with abundant apoptotic cells of oysters. Images of the TUNEL assay on histological sections. Fig. 11. Branchial lesion with positive cells showing brown deposits (arrows) in branchial epithelium and connective tissue $(*)$. Scale bar $=50 \mathrm{~mm}$. Fig. 12. Detail of a branchial lesion showing numerous positive cells in the tip of the gill plica (arrows). Scale bar $=20 \mathrm{~mm}$. Fig. 13. Enlargement of a gill filament with positive cells (arrows). Scale bar $=10 \mathrm{~mm}$. Fig. 14. Image of the gill of an oyster without branchial lesions. No brown deposit is shown. Scale bar $=50 \mathrm{~mm}$. Figs. 15 \& 16. Apoptotic cells in healthy tissues of oysters with branchial lesions. Images of the TUNEL assay on histological sections. Fig. 15. Apoptotic cells (arrows) in stomach epithelium. Scale bar $=50 \mathrm{~mm}$. Fig. 16. Apoptotic cells (arrows) in gonad follicles. Scale bar $=50 \mathrm{~mm}$ 


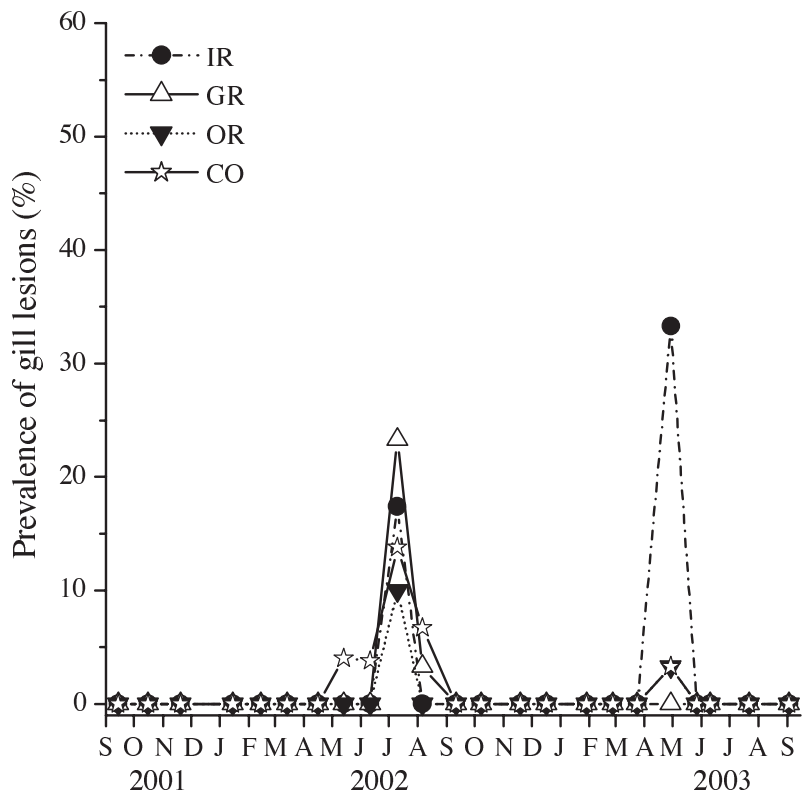

Fig. 17. Ostrea edulis. Monthly variation in the mean prevalence of gill lesions with profuse apoptosis in oysters from each origin. IR: Ireland; GR: Greece; OR: Ortigueira; CO: Coroso

Navarre \& Zychlinsky 2000). TEM was used to assess the occurrence of viral or prokaryotic organisms that may have gone unnoticed with light microscopy. No pathogen was detected; thus, the etiology remains unknown. Two diseases cause extensive branchial lesions in oysters of European coasts: bonamiosis of Ostrea edulis and the gill disease of Portuguese oysters Crassostrea angulata. In this work, the oysters with gill lesions associated with profuse apoptosis did not show histological evidence of either Bonamia ostreae or gill disease, the latter of which is characterized by the presence of giant cells with hypertrophied nucleus and the occurrence of iridovirus (Comps \& Duthoit 1979). Renault \& Cochennec $(1994,1995)$ reported Rickettsia and Chlamydia in epithelial and mantle cells of the Japanese oyster caused heavy haemocytic infiltration, but they were not detected in this study.

With regard to histology and cytology, the most remarkable characteristic of the lesions was the abundance of atypical cells showing apoptotic features similar to those described in human cells undergoing apoptosis (Arends \& Wyllie 1991). A characteristic of apoptotic cells is that they are rapidly recognized (Williamson \& Schlegel 2004) and phagocytosed for later destruction (Arends \& Wyllie 1991). In the present study, apoptotic cells were observed inside the cytoplasm of another cell, suggesting phagocytosis had occurred. Degradation of nuclear and cytoplasmic structures was also observed. The TUNEL assay con-
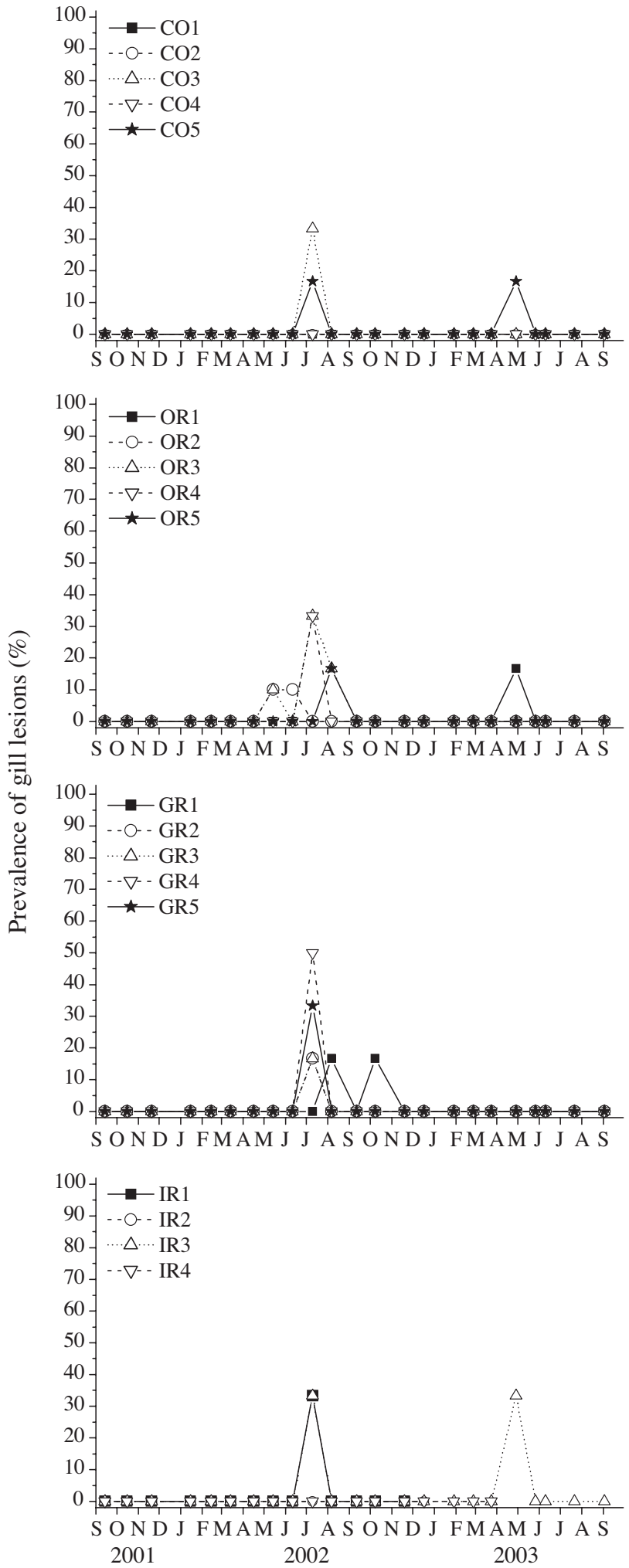

Fig. 18. Ostrea edulis. Monthly variation in the prevalence of gill lesions with profuse apoptosis in oysters of each family from every origin. Families of each origin are identified by numbers. CO: Coroso; OR: Ortigueira; GR: Greece; IR: Ireland 
firmed the presence of abundant apoptotic cells in branchial lesions.

The ultrastructural study of the apoptotic cells did not reveal typical morphological characteristics of branchial epithelial cells such as microvilli or cilia on the surface and desmosomes connecting them. There were no intracellular organelles such as vesicles containing mucus in apical cytoplasm, which suggests that the type of cell involved in the branchial lesions were apoptotic haemocytes. It is important to note that there are many haemolymph sinuses in the plicae and in the filaments of the gill that provide haemocytes for several functions in the gill. Haemocytes are recruited from circulation to sites of inflammation and tissue damage (Cheng 1996). This fact could explain why apoptotic cells were observed in many spaces of the connective tissue of the gill and supports the hypothesis that the apoptotic cells were haemocytes.

Apoptosis, or programmed cell death, is a normal physiologic process for the orderly removal of effete cells (see review of White 1996). Apoptosis plays a key role in maintaining white blood cell counts in vertebrates, and suppression of apoptosis would cause serious diseases such as leukemia (Cohen et al. 1992). Sunila \& LaBanca (2003) reported high numbers of apoptotic haemocytes in healthy oysters in the connective tissue underlying the stomach and intestine epithelia and suggested that it was part of the normal haemocyte renewal process. In the present study, the abundance of apoptotic cells and the haemocytic infiltration observed in the gill lesions should not be considered normal. Goedken et al. (2005a) reported apoptosis rate of $1 \%$ in circulating haemocytes from the eastern oyster Crassostrea virginica with TUNEL assay. The abundance of apoptotic haemocytes in the branchial lesions clearly exceeded that. Apoptotic haemocytes were not observed in the gills of oysters without lesions. This is in accordance with Sunila \& LaBanca (2003), who did not observe apoptotic haemocytes in the gills of healthy $C$. virginica, while some of the ciliated gill epithelial cells were apoptotic. In other organs without lesions (stomach, gonad follicles) apoptotic cells were observed in low number and without inflammatory reaction. Haemocytic infiltration is part of the innate cellular defense mechanism in bivalves, but in the condition described in this paper haemocytes caused massive lesions and distortion of the gill structure. Since apoptosis per se does not elicit an inflammatory response (Vermes \& Haanen 1994), lesions described in the present paper may have been initiated by an inflammatory reaction followed by apoptosis of some of the haemocytes. Apoptosis was reported to tend to limit inflammatory tissue damage and promote resolution rather than progression by removing granulocytes in mammals (Haslett et al.
1994). However, phagocytosis of apoptotic cells stimulates the secretion of factors that may help to attenuate potential inflammation during clearance of these cells in mice (Odaka et al. 2003).

Most cases of branchial lesions associated with abundant apoptotic cells were detected in July 2002 and April 2003: short and rare episodes that affected all origins and almost all families. This suggests the influence of an external rather than an intrinsic oyster factor. The gill of the oyster is the organ most directly exposed to environmental pollutants or other toxic compound occurring in seawater. A hypothesis that could explain this result is that a toxic phytoplankton bloom could be responsible for the abundant apoptotic cells since okadaic acid, a toxin occurring in the dinoflagellates of the genera Dinophysis and Prorocentrum, was demonstrated to induce apoptosis in different cellular models (Cabado et al. 2003). The significance of this lesion to the flat oyster industry in Galicia is uncertain, although it should not be considered a serious threat. The severity of the lesions could cause organ dysfunction and, consequently, be lethal to the oyster. However, the episodes are infrequent.

Acknowledgements. M. I. Seoane and V. Rodríguez supervised all the work to produce oyster spat in the CIMA hatchery facilities. The Company 'Jose Maria Daporta Leiro e Hijos, S.L.', the shellfish farmers L. Nogueira, J. L. Nogueira and M. Nogueira and the 'Confraría de Pescadores Nosa Señora do Carmen de Cariño' helped with oyster grow-out and provided broodstock oysters. E. Penas, I. Meléndez, M. Andrade, P. Comesaña, I. Fernández, A. I. González, M. V. Gregorio, A. C. Iglesias and C. Rodríguez provided field and laboratory technical assistance. Shannon Kelly helped to edit the manuscript. This work was partially supported by funds from the 'Secretaría Xeral de Investigación e Desenvolvemento Tecnolóxico da Xunta de Galicia', through the project PGIDT-CIMA 01/1. P.M.S. was supported by successive scholarships from the 'Agencia Española de Cooperación Internacional' (AECI) and the 'Conselho Nacional de Desenvolvimento Científico e Tecnológico' (CNPq) of the Brazilian Government.

\section{LITERATURE CITED}

Aoshiba KA, Rennard SI, Spurzem JR (1997) Cell-matrix and cell-cell interaction modulate apoptosis of bronchial epithelial cells. Am J Physiol 272:L28-L37

Arends MJ, Wyllie AH (1991) Apoptosis: mechanisms and roles in pathology. Int Rev Exp Pathol 32:223-254

Barcinski MA, DosReis GA (1999) Apoptosis in parasites and parasite-induced apoptosis in the host immune system: a new approach to parasitic diseases. Braz J Med Biol Res 32:395-401

Buckley CD, Pilling D, Henriquez NV, Parsonage G and 6 others (1999) RGD peptides induce apoptosis by direct caspase-3 activation. Nature 397:534-539

Cabado AG, Leira F, Vieites JM, Vieytes MR, Botana LM (2003) Caspase-8 activation initiates okadaic acid-induced apoptosis in neuroblastoma. In: Villalba A, Reguera B, Romalde J, Beiras R (eds) Molluscan shellfish safety. 
Xunta de Galicia, Intergovernmental Oceanographic Commission of UNESCO, Santiago de Compostela, p 107-117

Cheng TC (1996) Hemocytes: forms and functions. In: Kennedy VS, Newell RIE, Eble AF (eds) The eastern oyster, Crassostrea virginica. A Maryland Sea Grant Book, College Park, MA, p 299-333

Cohen JJ, Duke RC, Fadok VA (1992) Apoptosis and programmed cell death in immunity. Annu Rev Immunol 10: 267-293

Comps M, Duthoit JL (1979) Infections virales chez les huitres Crassostrea angulata Lmk. et Crassostrea gigas Th. Haliotis 8:301-307

da Silva PM, Fuentes J, Villalba A (2005) Growth, mortality and disease susceptibility of oyster Ostrea edulis families obtained from brood stocks of different geographical origins, through on growing in the Ría de Arousa (Galicia, NW Spain). Mar Biol 147:965-977

de la Fuente HD, Portales-Perez D, Baranda L, Díaz-Barriga F, Saavedra-Alanis V, Layseca E, Gonzalez-Amaro R (2002) Effect of arsenic, cadmium and lead on the induction of apoptosis of normal human mononuclear cells. Clin Exp Immunol 129:69-77

Gavrieli Y, Sherman Y, Ben-Sasson SA (1992) Identification of programmed cell death in situ via specific labeling of nuclear DNA fragmentation. J Cell Biol 119:493-501

Goedken M, Morsey B, Sunila I, Dungan C, De Guise S (2005a) The effects of temperature and salinity on apoptosis of Crassostrea virginica hemocytes and Perkinsus marinus. J Shellfish Res 24:177-183

Goedken M, Morsey B, Sunila I, De Guise S (2005b) Immunomodulation of Crassostrea gigas and Crassostrea virginica cellular defense mechanisms by Perkinsus marinus. J Shellfish Res 24:487-496

Haslett C, Savill JS, Whyte MK, Stern M, Dransfield I, Meagher LC (1994) Granulocyte apoptosis and the control of inflammation. Philos Trans R Soc Lond B Biol Sci 345: $327-333$

Lacoste A, Cueff A, Poulet SA (2002) P35-sensitive caspases, MAP kinases and rho modulate beta-adrenergic induction of apoptosis in mollusc immune cells. J Cell Sci 115: 761-768

Mičić M, Bihari N, Labura Ž, Müller WEG, Batel R (2001) Induction of apoptosis in the blue mussel Mytilus galloprovincialis by tri-n-butyltin chloride. Aquat Toxicol 55: $61-73$

Editorial responsibility: Albert K. Sparks, Seattle, Washington, USA
Mičić M, Bihari N, Jakšić Z, Müller WEG, Batel R (2002) DNA damage and apoptosis in the mussel Mytilus galloprovincialis. Mar Environ Res 53:243-262

Navarre WW, Zychlinsky A (2000) Pathogen-induced apoptosis of macrophages: a common end for different pathogenic strategies. Cell Microbiol 2:265-273

Odaka C, Mizuochi T, Yang J, Ding A (2003) Murine macrophages produce secretory leukocyte protease inhibitor during clearance of apoptotic cells: implications for resolution of the inflammatory response. J Immunol 171: $1507-1514$

Renault T, Cochennec N (1994) Rickettsia-like organisms in the cytoplasm of gill epithelial cells of the Pacific oyster Crassostrea gigas. J Invertebr Pathol 64:160-162

Renault T, Cochennec N (1995) Chlamydia-like organisms in ctenidia and mantle cells of the Japanese oyster Crassostrea gigas from the French Atlantic coast. Dis Aquat Org 23:153-159

Renault T, Le Deuff RM, Chollet B, Cochennec N, Gérard A (2000) Concomitant herpes-like virus infections in hatchery-reared larvae and nursery-cultured spat Crassostrea gigas and Ostrea edulis. Dis Aquat Org 42:173-183

Román G (1992) Efecto del ciclo reproductivo y el acondicionamiento en el desarrollo larvario, la fijación y el posterior crecimiento de la semilla de Ostrea edulis Linné 1758. Publ Espec Inst Esp Oceanogr 1-172

Sokolova IM, Evans S, Hughes FM (2004) Cadmium-induced apoptosis in oyster hemocytes involves disturbance of cellular energy balance but no mitochondrial permeability transition. J Exp Biol 207:3369-3380

Sunila I, LaBanca J (2003) Apoptosis in the pathogenesis of infectious diseases of the eastern oyster Crassostrea virginica. Dis Aquat Org 56:163-170

Terahara K, Takahashi KG, Mori K (2003) Apoptosis by RGDcontaining peptides observed in hemocytes of the Pacific oyster, Crassostrea gigas. Dev Comp Immunol 27:521-528

Vermes I, Haanen C (1994) Apoptosis and programmed cell death in health and disease. Adv Clin Chem 31:177-246

White E (1996) Life, death, and the pursuit of apoptosis. Gene Dev 10:1-15

Williamson P, Schlegel RA (2004) Transbilayer phospholipid movement and the clearance of apoptotic cells. Biochim Biophys Acta 1585:53-63

Wyllie AH (1980) Glucocorticoid-induced thymocyte apoptosis is associated with endogenous endonuclease activation. Nature 284:555-556

Submitted: August 5, 2005; Accepted: December 28, 2005

Proofs received from author(s): May 3, 2006 